\title{
Chemical characteristics of seed oil from wild prickly pear (Opuntiaficus - indica) in eastern Morocco
}

\author{
Ahmed Marhri1,", Kamal Belhaj ${ }^{1,3}$, Reda Melhaoui ${ }^{1}$, Aziz Tikent ${ }^{1}$, Abdessamad Benmoumen ${ }^{1}$, Aatika Mihamou ${ }^{1}$, Hana \\ Serghini-Caid ${ }^{1}$, Ahmed Elamrani ${ }^{1}$, Christophe Hano $^{2}$, Malika Abid ${ }^{1}$ and Mohamed Addi ${ }^{1}$ \\ ${ }^{1}$ Laboratory for Agricultural Productions Improvement, Biotechnology and Environment (LAPABE), Faculty of Sciences, \\ University Mohammed First, BP-717, 60000 Oujda, Morocco. \\ ${ }^{2}$ ligneous and Field Crops Biology Laboratory, INRA USC1328, Orleans University, CEDEX 2, 45067 Orléans, France. \\ ${ }^{3}$ Laboratory of Sustainable Agriculture Management, Higher School of Technology Sidi Bennour, University Chouaib Doukkali, \\ Street Jabran Khalil Jabran BP 299-24000 El Jadida
}

\begin{abstract}
Prickly pear cactus (Opuntia ficus indica), is a Cactaceae plant with a great economic relevance in the world. Nowadays, nopal cactus industry is active and rapidly expanding.In fact, the seeds oil sector is the best exploitation due to the high price of this oil. Moisture content, oxidative stability, quality index, total phenol, flavonoids, chlorophyll and carotenoid contentof prickly pear seed oil were analyzed.The seeds used in this study were provided by a cooperative DAR ATABIAA located in Chouihia (Eastern region of Morocco) during the harvesting season 2020. The samples were obtained from wild trees grown in this region. Results showed that moisture content of prickly pear seeds was $9.12 \%$, whereas the acidity and peroxide index value was $1.11 \%$ and 4.44 meq $\mathrm{O} 2 / \mathrm{kg}$ respectively, andan oxidative stabilityof 17.31 hours. The total phenolic and the flavonoid content values for theseseed oilsare $260.07 \mathrm{mg} / \mathrm{kg}$ and $65.99 \mathrm{mg} / \mathrm{kg}$, respectively. Furthermore, the results show a carotenoid contentof $0.61 \mathrm{mg} / \mathrm{kg}$ and total chlorophyll of $1.52 \mathrm{mg} / \mathrm{kg}$.
\end{abstract}

\section{$1 \quad$ Introduction}

Prickly pear (Opuntiaficus indica), a member of the Cactaceae family, originally fromAmerican continent more exactly from the south of this continent.Grows abundantly in arid and semi-aridregions around the world, including Mediterranean countries, South Africa, Middle East, India, Australia and other areas[1] and grows everywhere in Morocco[2].Prickly pear speciesare well-adapted to arid lands and to a variety of climates, theygrow wild in areas with restrictedaccess to water, limiting the development of a lot of succulent food plants[2].On one side, this plant arecultivated in dry regions as an important nutrient and food source, anditcan alsobe used as natural wind break barrier, helping to protect the soil from the spread of the desert and controlling erosion[2].Moreover, Prickly pears are considered to be a versatile plant thatcan be cultivated and grown for usein several field, including food, cosmetic and pharmaceutical industries[2]. On the other side, the cultivation ofthis plant requires little investment. All these characteristics have contributed toan unceasing extension of this culture in several areas all over the world, and the plant is becoming increasingly economically important[1]. The fruit is the most consumed part of the plant, it contains around 300 seeds (2\% to $10 \%$ of the fruit)[1], while the pericarp and the pulp of the fruits accounts for 33 to $55 \%$ and 45 to $67 \%$ respectively[3].However,until now, this part of the fruit(seeds) remains poorly exploited. In fact, Millions of pounds of seeds are thrown away each year as waste[4], although proper utilization of these byproducts leads to a production of a very important and a costly oil. Prickly pear seed oils (PPSO) are of great interest because they are edible oils with high level of unsaturationand antioxidant radical scavenging properties[5].This oil has been shown to have considerable amounts of antimicrobial, biological activity, cardio protective, antithrombotic, anti-inflammatory, anti-arrhythmic, hypolipidemic and anti-hyperglycemic[4]. The seeds are composed mainly by $45.1 \mathrm{wt} \%$ of cellulose, followed bylipids (23\%)[6]. Thus, they are rich in albumin protein with $6.5 \mathrm{kDa}$ molecularweight, and proanthocyanidins withstrong antioxidant activity [7], they are composed by $49.6 \%$ fiber, 17 fat, $16.6 \%$ protein and 3.0\% ash.Aspartic acid, glutamic acid, arginine and glycine make up the most abundant part

*Email: ahmed20maghri@gmail.com 
of the amino acids [8].According to literature data ,Opuntia ficus indicaseed oil is characterized by a fairly low acidity (1.27\% ) [9] andPeroxide values ranged between 9.50 and 33.67 meq O2/kg,another study conducted by De Wit, Hugo [10]revealed that these oils have a relatively low owidative stability ranging between 2.16 and 4.15 h.Thus, this previous research has shown that chemical properties such as peroxide number and oil content correlate with oxidative stability.According to Khemiri and Bitri [11], PPSOhas a totalphenolic and the flavonoidcontentof 26.5 Gallic acid eq/g and $3.1 \mathrm{mg}$ Quercetineq $/ \mathrm{g}$ respectively,carotenoid content $(10.52 \mathrm{mg} / \mathrm{kg}) \mathrm{oil} \mathrm{and} \mathrm{a} \mathrm{total}$ chlorophyll content of $4.57 \mathrm{mg} / \mathrm{kg}$.

The oil content and composition are influenced by the environmental and genetic factors such as soil, cultivar and geographical area[12].Moisture content, oxidative stability, quality index, and pigments contentof Opuntia ficusindicaseed oil from Chouihia region of eastern Morocco were investigated in this study. These chemical properties will provide further information on the valorization of seeds in various fields, such as the food, cosmetic, and pharmaceutical industries. The results were compared with other studies to evaluate the quality of this vegetable oil from Eastern Morocco.

\section{Material and Methods}

\subsection{Samples and plant material}

Prickly pear seeds used in this study were extracted from the fruits provided by the cooperative DAR ATABIAAobtained from wild trees locatedin rural zone of Chouihia (Berkane Province) eastern Morocco.The fruits were peeled by hand, and the pulps were scraped from the seeds with multiple washes of water. The seeds were then dried externally in the sun. The oil was extracted via mechanical pressing which is the most prevalent method for obtaining oils in the world[13].

\subsection{Moisture content}

The determination of the moisture percentage of the seeds was carried out according to AOAC [14], 2 g of prickly pear seeds are dried in stove at $103^{\circ} \mathrm{C}$ for 3 hours until weight stability, are then placed in the desiccator for one hour before being weighed.

The loss of mass found after steaming is then equated with the mass of water contained in the product. The moisture content is equal to the average of the results of the grading tests, expressed in $\mathrm{g}$ of water $/ 100 \mathrm{~g}$ of seed.

$$
\text { Humiditylevel }(\%)=[(P 2-P 3) \div(P 2-P 1)] \times 100
$$

P1 : mass in grams of the tare vessel

P2 : mass in g of (tare vessel + sample) before drying

P3 : mass in $\mathrm{g}$ of (tare vessel + sample) after drying

\subsection{Free acidity}

The acidity was determined according to the official method of the European Commission (EEC, 2003).Acidity value determines the percentage of free fatty acid expressed by the major fatty acid (linoleic) present in the oil resulting from the hydrolysis of triglycerides.Using the official method of the European Commission: $0.5 \mathrm{~g}$ of Opuntia ficus indica oil was dissolved in $5 \mathrm{ml}$ of a mixture of absolute ethanol and diethyl ether $(2.5 \mathrm{ml}, 2.5$ $\mathrm{ml} ; \mathrm{v} / \mathrm{v})$, to which eight drops of phenolphthalein (1\%) were added. The free fatty acids are titrated under agitation by an alcoholic solution of $0.1 \mathrm{~N}$ potassium hydroxide (the pink color of the phenolphthalein persists for at least 10 seconds). The free acidity is calculated according to the following formula[15]:

$\mathrm{C}(\mathrm{KOH}): \mathrm{KOH}$ concentration expressed in $\mathrm{mol} / \mathrm{l}$

$$
\% \text { of linoleic acid }=\frac{\mathrm{C}(\mathrm{KOH}) \times \mathrm{V}(\mathrm{KOH}) \times \mathrm{M}(\mathrm{C} 18 \mathrm{H} 32 \mathrm{O} 2)}{\text { P.E }}
$$

$\mathrm{V}(\mathrm{KOH})$ : Poured volume of $\mathrm{KOH}$ expressed in $\mathrm{ml}$

P.E : test sample in gram 


\subsection{Peroxide index}

The peroxide indice is used to estimate the content of the primary oxidation products present in the oil (hydroperoxides), which is expressed in meq $\mathrm{O} 2 / \mathrm{kg}$ of oil.This index is determined by the so-called acetic acid and chloroform method according to the AOAC [14]standard.Acetic acid-chloroform mixture (15:20 v/v) was used to dissolve $1 \mathrm{~g}$ of tested oil. To this solution, $0.5 \mathrm{ml}$ of a saturated solution of potassium iodide (KI)is added. Finally, $30 \mathrm{ml}$ of distilled water is added to the mixture after one minute of stirring. This solution titrated with $0.01 \mathrm{~N}$ sodium thiosulfate using starch as a color indicator (colored indicator starch paste). The Peroxide values calculated according to the following equations.

$$
\text { Peroxide index }(\text { meq } 02 / \mathrm{Kg})=\frac{(\mathrm{Vt}-\mathrm{Vw}) \times 0.01 \times 1000}{\mathrm{P} . \mathrm{E}}
$$

Vt $\quad$ :Volume in $\mathrm{ml}$ of sodium thiosulphate added to the titration

Vw : Volume in $\mathrm{ml}$ of sodium thiosulphate used for the white.

P.E : test sample in grams

\subsection{Oxidative stability}

The stability oxidative was estimated viathe measure of induction time (oil resistance to thermo-oxidative stress) using the Rancimat 743(Metrom Co., Basel, Switzerland). In order to achieve this, 3g of oil was weighedand placed in a heating block at $100^{\circ} \mathrm{C}$. The principle of this method is to accelerate the aging of the oil by thermo-oxidative deterioration. The degradation products resultsare transferred to the measuring cell containing distilled water, and a conductivity meter was used in measuring. The operating conditions are as follows: an air flow rate of $20 \mathrm{~L} / \mathrm{h}$ and a temperature of $100^{\circ} \mathrm{C}$ (Delta T: $\left.1.6^{\circ} \mathrm{C}\right)[16]$. The result was expressed in hours.

\subsection{Determination of chlorophyll and carotenoids content}

The analysis of the chlorophyll and carotenoid content (expressed in $\mathrm{mg} / \mathrm{kg}$ ) was determined by the colorimetric method described byIsabel Minguez-Mosquera, Rejano-Navarro [17]. 1.5g of oil was dissolved in $5 \mathrm{~mL}$ cyclohexane, and the absorption was measured with a uvspectrophotometer (RAYLEIGH UV1800; UV-Visible)at $670 \mathrm{~nm}$ for chlorophylls and 470 nmfor carotenoids. The content of these pigments is calculated by the following equations:

$$
\begin{aligned}
& \text { Chlorophyll mg/kg }=\frac{\mathrm{A} 670 \times 106}{613 \times 100 \times \mathrm{d}} \\
& \text { Carotenoid mg/kg }=\frac{\mathrm{A} 470 \times 106}{2000 \times 100 \times \mathrm{d}}
\end{aligned}
$$

$\begin{array}{ll}\text { A470 } & \text { :Absorbance at wavelength } 470 \mathrm{~nm} \\ \text { A670 } & \text { : Absorbance at wavelength } 670 \mathrm{~nm} \\ \mathrm{~L} & \text { : Tank thickness in } \mathrm{cm}\end{array}$

\subsection{Determination of total phenolic content}

The extraction of phenolic compounds from cactus seed oil done using liquid-liquidextractionmethod described by Khemiri and Bitri [11]. In a centrifuge tube, $2 \mathrm{ml}$ of methanol/water mixture (80/20, V/V) are addedto $2 \mathrm{~g}$ of cactus oil. After stirring for 10 minutes, the tubes are centrifuged for $15 \mathrm{~min}$ at $3000 \mathrm{rpm}$. The hydro-methanolic phase was recovered by a Pasteur pipette. This extract is then used for the colorimetric determination by the Folin-Ciocalteu reagent in order to determine the total content of phenolic compounds[18].2 $\mathrm{ml}$ of each polyphenol extract are added to $1 \mathrm{ml}$ of Folin-Ciocalteu reagent diluted 10 times in distilled water, and $1 \mathrm{ml}$ of an aqueous solution of $10 \%$ $\mathrm{Na} 2 \mathrm{CO} 3(\mathrm{P} / \mathrm{V})$. After stirring, this solutionwas put in the obscurity for $90 \mathrm{~min}$ at room temperature, the absorbance measurements are carried out using a UV-visible spectrometer (RAYLEIGH UV1800) at $760 \mathrm{~nm}$. Total phenolic were expressed as $\mathrm{mg}$ of Gallic acid equivalents per $\mathrm{g}$ of oil (G.A. eq/g oil) [1].

Expression of results: 


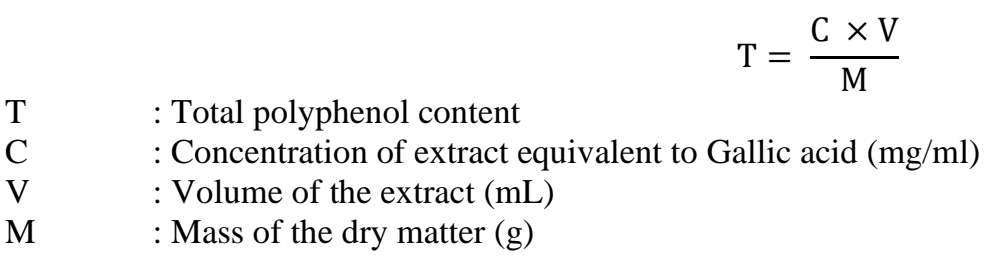

\subsection{Total Flavonoid Content}

The Bahorun method[19] was employed to determine the total flavonoids in extracts, and aluminumtrichloride (AlCl3) was utilized to quantify the flavonoids in the various extracts. $1.5 \mathrm{~mL}$ of each extract is added to $1.5 \mathrm{ml}$ of an $\mathrm{AlCl} 3$ solution (2\% in methanol),after $30 \mathrm{~min}$ of incubation in the dark, the absorbance is measured at 430nm[20]using a UV-visible spectrometer (RAYLEIGH UV1800). The flavonoids concentration is deduced from a calibration range established with quercetin at different concentrations.

Expression of results:

$$
T=\frac{C \times V}{M}
$$

$\mathrm{T} \quad$ : Flavonoid content

C : Equivalent extract concentration in quercetin $(\mathrm{mg} / \mathrm{ml})$

$\mathrm{V} \quad$ : Volume of the extract $(\mathrm{ml})$

M : Mass of the dry matter $(\mathrm{g})$

\section{Results and Discussion}

\subsection{Moisture Content of prickly pear seeds}

The amount of water detected in prickly pear seeds in the current study was $(9.12 \mathrm{~g} / 100 \mathrm{~g})$, which is generally a low value compared to other species[21, 22].In fact, this reduction of water content is one of the mechanisms adopted by cactus to reduce respiration, which causes oxidation and stockdepletion. Therefore, the seeds of prickly pear resist well to dehydration, In other words, water reduction is a strategy to increase the viability of the seeds, which is why they are classified orthodox seeds. In comparison with the results found in the literature, our finding found slightly higher compared to that of Bahorun, Gressier [19], Karabagias, Karabagias [4], BENATTIA [20], and El Mannoubi, Barrek [9], which are 6.0, 6.0, 6.43, and $6.9 \mathrm{~g} / 100 \mathrm{~g}$ respectively.Our study shows a slightly high humidity, which may be due to the climatic conditions of the eastern region, which are more favourable in comparison with the arid climate.Moreover, the high moisture content probably gives information about the water absorption capacity of the wild cultivar and the soil conditions.

The obtainedresults of acidity, peroxide index, total phenol, flavonoids, chlorophyll and carotenoid content of prickly pear seed oil are presented in the table 1.

Table 1: Chemical characteristics of wild prickly pear (Opuntia ficus indica) seed oil in eastern Morocco

\begin{tabular}{lcccc}
\hline \multicolumn{1}{c}{$\begin{array}{c}\text { Chemical quality } \\
\text { parameters }\end{array}$} & Mean & SD & Min & Max \\
\hline Acidity \% & 1.11 & 0.03 & 1.09 & 1.15 \\
Peroxide $\left(\mathrm{meqO}_{2} / \mathrm{kg}\right)$ & 4.44 & 0.44 & 3.99 & 4.88 \\
Stability oxidative $(\mathrm{h})$ & 17.31 & 1.79 & 16.33 & 20.94 \\
Phenol $(\mathrm{mg} / \mathrm{kg})$ & 260.07 & 30.1 & 201.19 & 314.9 \\
Flavonoid $(\mathrm{mg} / \mathrm{kg})$ & 65.99 & 12.77 & 46.33 & 84.95 \\
Chlorophyll $(\mathrm{mg} / \mathrm{kg})$ & 1.52 & 0.19 & 1.12 & 1.69 \\
Carotenoid $(\mathrm{mg} / \mathrm{kg})$ & 0.61 & 0.03 & 0.55 & 0.63 \\
\hline
\end{tabular}

SD: standard deviation 


\subsection{Quality index}

The measurementof free acidity is the main parameters used to determine oil quality and therefore provides information on its aging. Over time, the triacylglycerolshydrolyze to free fatty acids and glycerol,the degraded oil contains more free acids, consequently, higher acidity index.The recordedvalue of this parameter was about $1.11 \%$ of linoleic acid (table 1). This result is lowercomparable to that obtained by El Mannoubi, Barrek [9] whofound a free acidity value of $1.27 \%$. In addition our outcome is higher thanthatrecorded byKarouiet al[23](0.27\%), and isslightly lower compared tothe value reported byOzcanet al[24]and by Khemiri and Bitri [11] whofound a free acidity about $1.41 \%$ and $1,95 \%$ respectively.

According to the joint Food and Agriculture Organization/World Health Organizationfood standards program codex alimentarius commission 2019, the examination of hydroperoxides allows for the determination of the oxidation stage of fatty acid. The acceptable peroxide value must be less than $20 \mathrm{meq} \mathrm{O} / \mathrm{kg}$ for Virgin oils. The obtained value ( 4.44 meq $\mathrm{O} 2 / \mathrm{kg}$ ) is below the standard for virgin oil. This result allows us to concludethat the studied oil has a less oxidized.In comparison with other studies, this value was slightly higher compared to the results reported byKaroui, Ayari [23] (3.71 meq O2/kg)and much higherthan the finding ofOzcan and Al Juhaimi [24],andKhemiri and Bitri [11]who found (1.63 meq O2/kg) and $(2.230 \mathrm{meq} \mathrm{O} / \mathrm{kg})$, respectively.Low acidity and peroxide values indicate a low degree of deterioration of the tested oil, these quality indices are mainly affected by several factors such as improper harvesting systems, transportation, storage of the fruit, and in particularoil extraction method.In fact, the oil acidity increased during storage of fruit. It was highest when fruit were stored at $7.5^{\circ} \mathrm{C}$ and decreased with lower storage temperature.Oil stored in a controlled atmosphere had lower acidity than oil stored in air. The increase in acidity was probably the result of fungal lipase activity[25]. Regarding the peroxide value of oil obtained from fruit stored at various temperatures and controlled atmospheres increased during storage, compared to oil from freshly harvested fruit. The increase was significant only for fruit stored at $7.5^{\circ} \mathrm{C}[25]$.

\subsection{Oxidative stability}

The induction time in the Rancimat test is used to assess oxidation sensitivity to thermo-oxidative stress.According to the literature, cactus oils have a relatively low oxidative stability index ranging from 1.79 to 4.15 hours[10, 26]. This higher sensitivityis due mainly to its richness in polyunsaturated fatty acids. However, the studied seed oil obtained from wild cultivar of Chouihia region shows higher stability oxidative index (17.31 hours), which is confirm the lower recorded value of acidity and peroxide index.This higher SOI recorded could be linked to thephenol and chlorophyll content.Similar results have been demonstrated by Salama, El Harkaoui [16]who found that natural antioxidant richness increases the SOI for vegetable oil.

\subsection{Total phenolic and flavonoid content}

The phenolic and flavonoids compounds have significant antioxidant activities and are classified among the most main antioxidants in the oils. This secondarymetabolites are considered as a determining factors in term of organoleptic quality[27]. The flavonoids are the most important polyphenolic class. This bioactive molecules are to be able to liberate the hydrogen that allows oxidative stability improvement [26].The colorimetric evaluation of the total phenolic and flavonoid content show that the studied seed oil of prickly pear has a value of $260.07 \mathrm{mg} / \mathrm{kg}$ and $6.599 \mathrm{mg} / \mathrm{kg}$ (table 1), respectively. Concerning the total phenol content, our results arelower than those found by Karabagias, Karabagias [4], which reported a total phenol concentration of $551 \mathrm{mg} / \mathrm{kg}$. The process of oil extraction affects the amount of polyphenols, and therefore decrease the content of this natural antioxidants resulting inlow oxidation resistance.Indeed, the total phenolic content were rised with increasing temperature[28].Regarding the flavonoid, the estimated value is lower than that reported by Chavez-Santoscoy, Gutierrez-Uribe [29] who found a values ranging between 95 and $374 \mathrm{mg} / \mathrm{kg}$ respectively.This difference could be explained by the difference in the method utilized and the conditions extraction, which have an impact on the total concentration of phenols and flavonoids, and hence on antioxidant activity[30].The richness in polyphenol increases the interest of the oil,since itreduces glucose level in the blood and lowered level of bad cholesterol. Polyphenols arenatural calming and antifatigue compounds, and have a sedative action in conditions such as angina, heart spasms, headaches and stomach aches[20]. 


\subsection{Carotenoidand chlorophyll content}

These two natural components are the majorpigments of vegetable oil, ensuring an orange, red, or yellow color [31]. Green oils are rich in chlorophyll pigments, whilst oils with high levels of carotenoids are more yellowish [32].Because of their antioxidant nature in the dark and pro-oxidant nature in the light[28-29], chlorophyll play an important role in the oxidative activity of the oil during storage and in the preservation of its quality.On the other hand, carotenoids are the photo-oxidation inhibitors, and are able to neutralize active-singlet oxygen or triplet activator [33].In the present study,Opuntiaficusindicaseed oil hasthe lowest carotenoid and chlorophyll contents with respectively0.61 and $1.52 \mathrm{mg} / \mathrm{kg}$. In comparison with theresults ofEl Mannoubiet al[9] $(8.01$ and $2.403 \mathrm{mg} / \mathrm{kg})$ the studied oil is lower in terms of pigments.The presence of these antioxidants has contributed in the remarkable improvement of the oxidative stability of this oil[9].

\section{Conclusion}

The chemical composition of PPSO has recently attracted the interest of scientists and experts. According to the results of this study, Chouihia PPSO is characterized by better oxidative stability on the one hand, richness in antioxidants on the other hand and could be considered as a good source of bioactive compounds (polyphenols, carotenoids and chlorophyll). This result shows that this Prickly Pear is a versatile plant and a source of bioactive components for industrial application for food and pharmaceutical purposes. Further studies are needed to better characterize this seed oil produced in eastern Morocco by evaluating fatty acid profile, triacylglycerol composition, tocopherols and phytosterols content.

\section{References}

1. M. Chbani, B. Matthaus, Z. Charrouf, H. El Monfalouti, B. Kartah, S. Gharby, and I. Willenberg, Foods, 9, (2020)

2. Z. Ghazi, M. Ramdani, M.-L. Fauconnier, B. El Mahi, R.J.J.o.M. Cheikh, and E. Science, 5, 967-972 (2013)

3. J. Arrizon, C. Calderón, G.J.J.o.I.M. Sandoval, and Biotechnology, 33, 921-928 (2006)

4. V.K. Karabagias, I.K. Karabagias, I. Gatzias, and A.V. Badeka, Processes, 8, (2020)

5. E. Ramírez-Moreno, R. Cariño-Cortés, N.d.S. Cruz-Cansino, L. Delgado-Olivares, J.A. Ariza-Ortega, V.Y. Montañez-Izquierdo, M.M. Hernández-Herrero, and T. Filardo-Kerstupp, Journal of Food Quality, 2017, 1-8 (2017)

6. R. Ciriminna, R. Delisi, L. Albanese, F. Meneguzzo, M.J.E.J.o.L.S. Pagliaro, and Technology, 119, 1700013 (2017)

7. V. Bittrich, E.A.J.B.s. Maria Do Carmo, and ecology, 19, 319-321 (1991)

8. W. Sawaya, J. Khalil, and M.J.P.F.f.H.N. Al-Mohammad, 33, 91-97 (1983)

9. I. El Mannoubi, S. Barrek, T. Skanji, H. Casabianca, and H.J.C.o.N.C. Zarrouk, 45, 616-620 (2009)

10. M. De Wit, A. Hugo, N.J.J.o.f.p. Shongwe, and preservation, 41, e12898 (2017)

11. I. Khemiri and L. Bitri, Oxid Med Cell Longev, 2019, 1568720 (2019)

12. F. El Hachimi, A. El Antari, M. Boujnah, A. Bendrisse, and C. Alfaiz, Journal of Materials and Environmental Science, 6, 1488-1502 (2015)

13. R. Savoire, J.-L. Lanoisellé, E.J.F. Vorobiev, and B. Technology, 6, 1-16 (2013)

14. AOAC, Official Methods of Analysis of the Association of Official Analytical Chemists. 15 Edi. ed. Vol. 17. 1990, Washington: Association of Official Analytical Chemists.

15. F. Mansouri, A. Ben Moumen, G. Richard, M.-L. Fauconnier, M. Sindic, H. Serghini-Caid, et al. 24: 9 (2017).

16. M.A. Salama, S. El Harkaoui, I. Nounah, H. Sakr, M. Abdin, M. Owon, M. Osman, A. Ibrahim, Z. Charrouf, and B. Matthäus, Ocl, 27, (2020)

17. M. Isabel Minguez-Mosquera, L. Rejano-Navarro, B. Gandul-Rojas, A.H. SanchezGomez, and J.J.J.o.t.A.O.C.S. Garrido-Fernandez, 68, 332-336 (1991)

18. C. El Kar, A. Ferchichi, F. Attia, and J.J.J.o.f.S. Bouajila, 76, C795-C800 (2011)

19. T. Bahorun, B. Gressier, F. Trotin, C. Brunet, T. Dine, M. Luyckx, J. Vasseur, M. Cazin, J. Cazin, and M.J.A.-f. Pinkas, 46, 1086-1089 (1996)

20. F.K. BENATTIA, Analyse et Application des Extraits de pépains de Figues de Barbarie. 2018, 08-01-2018.

21. M. Amin, M. Hossain, and K. Roy, Journal of Food Engineering, 65, 83-87 (2004)

22. R. Ellis, T. Hong, and E. Roberts, Annals of Botany, 61, 405-408 (1988) 
23. I.J. Karoui, J. Ayari, N. Ghazouani, and M. Abderrabba, Ocl, 27, (2020)

24. M.M. Ozcan and F.Y. Al Juhaimi, Int J Food Sci Nutr, 62, 533-6 (2011)

25. A. Kiritsakis, G. Nanos, Z. Polymenopulos, T. Thomai, and E. Sfakiotakis, Journal of the American Oil Chemists' Society, 75, 721-724 (1998)

26. E.J.O.J.o.t.E.C. Regulation, 295, 57-66 (2003)

27. P. Andrewes, J.L. Busch, T. de Joode, A. Groenewegen, H.J.J.o.a. Alexandre, and f. chemistry, 51, 1415-1420 (2003)

28. H. Özdemir, E. Bakkalbaşı, and I. Javidipour, Journal of Food Science and Technology, 58, 2606-2616 (2020)

29. R. Chavez-Santoscoy, J. Gutierrez-Uribe, and S.J.P.F.f.H.N. Serna-Saldívar, 64, 146-152 (2009)

30. K.W. Lee, Y.J. Kim, H.J. Lee, C.Y.J.J.o.a. Lee, and f. chemistry, 51, $7292-7295$ (2003)

31. L. Cerretani, M.-J. Motilva, M.-P. Romero, A. Bendini, G.J.E.F.R. Lercker, and Technology, 226, 1251-1258 (2008)

32. O. Baccouri, A. Bendini, L. Cerretani, M. Guerfel, B. Baccouri, G. Lercker, M. Zarrouk, and D.D.B.J.F.C. Miled, 111, 322-328 (2008)

33. K. Viljanen, S. Sundberg, T. Ohshima, M.J.E.J.o.L.S. Heinonen, and Technology, 104, 353-359 (2002) 